\title{
Planting Arrangement, Population Density and Fertilizer Application Rate for White Maize (Zea mays L.) Production in Bandarban Valley
}

\author{
Mohammad Ali Akbar ${ }^{1}$, M. A. Siddique ${ }^{1}$, Mong Sanue Marma ${ }^{2}$, M. Moksedur Rahman ${ }^{1}$, \\ M. Rafiqul Islam Molla ${ }^{1}$, M. Matiar Rahman ${ }^{1}$, M. Jafar Ullah ${ }^{3}$, Mohammad Ashraf Hossain ${ }^{4}$, \\ Abdul Hamid ${ }^{1, *}$ \\ ${ }^{1}$ Agrarian Research Foundation, Dhaka, Bangladesh \\ ${ }^{2}$ Cotton Research Station, Balaghata, Bandarban, Bangladesh \\ ${ }^{3}$ Agronomy Department, Sher-e-Bangla Agricultural University, Dhaka, Bangladesh \\ ${ }^{4}$ Pulses Research Center, Bangladesh Agricultural Research Institute, Joydebpur, Gazipur, Bangladesh
}

\begin{abstract}
Email address:
kbdaliakbar@yahoo.com (M. A. Akbar), msiddique@gmail.com (M. A. Siddique), marma_mong@yahoo.com (M. S. Marma), makrahman@yahoo.com (M. M. Rahman),sus@citeco.net (M. R. I. Molla), matiarkrishibidseed@gmail.com (M. M. Rahman), jafarullahsau@gmail.com (M. J. Ullah), ashrafbdpre@gmail.com (M. A. Hossain), hamid50.arf@gmail.com (A. Hamid)

${ }^{*}$ Corresponding author
\end{abstract}

\section{To cite this article:}

Mohammad Ali Akbar, M. A. Siddique, Mong Sanue Marma, M. Moksedur Rahman, M. Rafiqul Islam Molla, M. Matiar Rahman, M. Jafar Ullah, Mohammad Ashraf Hossain, Abdul Hamid. Planting Arrangement, Population Density and Fertilizer Application Rate for White Maize (Zea mays L.) Production in Bandarban Valley. Agriculture, Forestry and Fisheries. Vol. 5, No. 6, 2016, pp. 215-224. doi: $10.11648 /$ j.aff.20160506.12

Received: August 3, 2016; Accepted: August 18, 2016; Published: October 15, 2016

\begin{abstract}
On-farm experiments were conducted in the Bandarban valley during dry season, October 2015 through March, 2016 to investigate the possibility of introducing white maize as human food. Yield response of two maize hybrids (PSC 121 and KS 510) planted in three different row arrangements was evaluated in one experiment. The other experiment determined the optimum fertilizer rate for maize hybrids. Grain yield ranged between 7,103 $\mathrm{kg}$ and 10,126 $\mathrm{kg}$ per ha across hybrids and planting arrangements. Hybrid PSC 121 recorded 19\% more yield than KS 510. Generally grain yield increased with increasing planting density. Planting in twin-rows giving 80,000 plants per ha produced $17.7 \%$ higher yield compared with planting in single rows $60 \mathrm{~cm}$ apart giving 66,667 plants per ha. Planting in twin-rows produced significantly higher yield compared with single rows. Application of fertilizers at $100 \%$ and $50 \%$ of recommended rate produced identical but significantly higher grain yield compared to $25 \%$ of recommended rates. Increase of maize grain yield was associated with the number of grains per ear and individual grain weight.
\end{abstract}

Keywords: Bandarban Valley, White Maize, Hybrids, Row Spacing, Planting Density, Fertilizer Rates, Grain Yield

\section{Introduction}

Maize (Zea mays L.) is one of the most important cereal crops providing major source of food in many countries of world. It is grown as a fodder, feed and food crop. It is also used as raw material for manufacturing pharmaceutical and industrial products. Globally, maize ranks third among the cereal crops next to rice and wheat. Rice is the major staple in Bangladesh. Globally yield growth of rice either stagnated or slowed down [1]. With the growing population and rising income, demand of food is on the increase in one hand, and shrinking of agricultural land due to urbanization, industrialization and infrastructure development on the other hand. Therefore, growing food keeping pace with the demand faces unprecedented challenges [2] while raising the yield and production of rice remains questionable [3]. It is against this backdrop, introduction of white maize in Bangladesh as human food can be a viable alternative for sustaining food 
security given the productivity of maize much higher than rice and wheat [4]. Modern white maize hybrids with a short growing season produce a softer, smaller kernel that contains about $72 \%$ starch, $10 \%$ protein, and $4 \%$ fat, supplying an energy density of $365 \mathrm{Kcal} / 100 \mathrm{~g}$ [5] as compared to rice and wheat. Maize provides many of the B vitamins and essential minerals along with fiber, but lacks some other nutrients, such as vitamin B12 and vitamin C, and is, in general, a poor source of calcium, folate, and iron [6]. People in many developed and developing countries produce and consume maize as staple food. White maize constitutes about $10 \%$ of the total maize production in the USA and is used for human food.

Maize has been a recent introduction in Bangladesh. Ricemaize cropping system has been expanded rapidly in the northern districts of Bangladesh [7] mainly in response to increasing demand for poultry feed [8]. Currently maize is planted to about 307,000 ha producing 2.12 million tons of grains annually [9]. In the Chittagong Hill Tracts (CHT) maize is grown since long as a secondary staple crop for the ethnic communities contributing to $2.1 \%$ of national production. It is planted in two seasons in the CHT; in the valleys during the post-monsoon dry season and in the sloping uplands during the rainy season as mixed crop with several cereal, vegetables and cash crops in traditional slashburn system called jhum farming. Mostly the indigenous varieties of maize are grown in the CHT. Grain yields of maize in Bangladesh are among the highest in the tropics [10], but the yield in the CHT is about $45 \%$ of national average [9]. Low yield of maize in CHT is attributed to varieties and agronomic practices adopted by the hill farmers. When grown in the valleys, farmers practice planting in rows usually at wider spacing using no fertilizers or inadequate amount of fertilizers.

Advances in breeding and biotechnology contributed to development of high yielding modern varieties and hybrids of maize that outyielded earlier varieties. Improvement of agronomic management practices also contributed greatly to increasing grain yields [11]. However, the yield performance differs remarkably across hybrids depending on environmental conditions [12] and agronomic management. Among the agronomic factors influencing the grain yield of maize, plant population density is the most important one $[13,14]$. Generally grain yield increases with increasing planting density [15], as higher plant densities enhance light interception and dry matter accumulation [16]. Maize grain yield per unit area shows a curvilinear response to plant population [17, 18], presenting a maximum yield at the optimum plant density. Potential higher yields of modern hybrids obtainable with higher population encouraged planting maize at narrower spacing [19]. Grain yield of individual plant of sparsely planted maize crop is usually high but because of low population the total grain yield per unit area remains low. However, several reports [e.g., 20, 21] indicated that row spacing had no influence on maize plant height, LAI, dry matter accumulation, net assimilation, HI and grain yield. High plant densities have been found to reduce kernel number per unit land area, decrease the number of kernels per ear [22], reduce harvest index and the overall grain yield [19]. In Bangladesh, a population density of 83,000 planted in rows at $60 \mathrm{~cm} \times 20 \mathrm{~cm}$ configuration gave the highest grain yield [23]. Optimum plant density, however, depends largely on genotype, season, available growth resources and agronomic management conditions.

Application of fertilizer is one of the major agronomic practices regulating potential yield in maize, since sufficient and timely nutrient supply affects both grain number and mean grain weight through adjusting grain formation, filling rate and duration [24]. Bender et al. [25] demonstrated that a modern hybrid maize with moderate yield potential takes up $287 \mathrm{~kg} \mathrm{~N}, 50 \mathrm{~kg} \mathrm{P}, 167 \mathrm{~kg} \mathrm{~K}, 26 \mathrm{~kg} \mathrm{~S}, 8 \mathrm{~kg} \mathrm{Zn}$ and $1.3 \mathrm{~kg} \mathrm{~B}$ per ha. Nitrogen $(\mathrm{N})$ is the major macronutrient determining the crop size and yield formation [26, 27]. A maize crop grown in Bangladesh during dry season with a planting density of 80,000 per ha and receiving $180 \mathrm{~kg} \mathrm{~N}$ per ha gave higher amount of grains per ear and maximum grain yield compared to lower population density receiving lower amount of fertilizers [28]. Higher yield was associated with maximum number of leaves plant ${ }^{-1}$, number of cobs plant ${ }^{-1}$, number of grains $\mathrm{cob}^{-1}$, taller plants, and greater biological yield. Phosphorus is essential for plant physiological processes, growth, development, grain formation, and ripening [29]. To produce $1.0 \mathrm{t}$ of grains, maize plants remove nearly $8.0 \mathrm{~kg}$ phosphorus per ha [30]. Deficiency of phosphorus results in small ears in maize due to crooked and missing rows as kernel twist. Application of $100 \mathrm{~kg} P$ per ha increased maize grain yield significantly [31]. Maize plants take up a large amount of potassium. A mature maize crop may contain up to $300 \mathrm{~kg} \mathrm{~K}$ per ha in aboveground plant material, mostly present in vegetative plant parts [32]. Smid and Peaslee [33] found a close correlation between $\mathrm{K}$ concentration in maize leaves and rate of photosynthesis. Increasing rate of $\mathrm{K}$ fertilizer application increases maize dry matter and grain yield. Small concentrations of boron are distributed in organs of maize plant [22] but it exerts a great influence on basic plant life processes. Boron contents of the soils in Bandarban valley are low to very low [34]. Reproductive growth in many plant species is adversely affected by boron deficiency. In maize, boron deficiency results in barren cobs [35]. Hossain et al. [36] showed that in a calcareous soil maize grain yield increased between 4 and $27 \%$ due to application of $\mathrm{Zn}$ at $3 \mathrm{~kg}$ per ha. Yield increase of $26 \%$ through boron application has been reported in India [37].

Optimizing the NPK fertilizer rates is necessary to achieve optimal yield potential of a cultivar. Cultivars differ in their response to nutrient supply when planted in different geographical environments. Khuong et al. [38] reported high planting density $(74,000$ plants per ha) and a moderate dose of fertilizer (200:120: $\mathrm{N}, \mathrm{P}_{2} \mathrm{O}_{5}, \mathrm{~K}_{2} \mathrm{O} \mathrm{kg}$ per ha) application resulted in higher grain yield of maize in Vietnam. Study on determining optimum fertilizer requirement of modern maize hybrids planted at higher densities in hilly region of Bangladesh has not been reported. In this study we evaluated 
yield performance two maize hybrids (PSC 121 and KS 510) planted at three different planting arrangements and yield response of maize to variable rates of fertilizer application. The specific objectives of the study were to (i) select a higher yielding maize hybrid for growing in Bandarban valley, (ii) optimize plant population density with appropriate planting arrangement; and (iii) determine fertilizer application rate for securing higher yield of maize.

\section{Materials and Methods}

\subsection{Experimental Location}

Two experiments were carried out in farmers' fields in four villages - Charuipara, Joymonpara, Bakicharamukh and Thwingyapara in the district of Bandarban during dry season, October 2015 through March 2016. The experimental sites were located between $21^{\circ} 14^{\prime}$ to $22^{\circ} 14^{\prime} \mathrm{N}$ latitude and $92^{\circ} 12^{\prime}$ to $92^{\circ} 14^{\prime} \mathrm{E}$ longitude at an average altitude of $10.4 \mathrm{~m}$ above mean sea level.

The experimental unit covered farmer's entire plot area for convenience and hence the plots accommodating the experiments varied greatly in size $\left(716 \mathrm{~m}^{2}\right.$ to $\left.2,088 \mathrm{~m}^{2}\right)$. Soils of experiments in Charuipara and Joymonpara were sandy loam in texture while those of Bakicharamukh and Thwingyapara were mostly of clayey in nature [34]. The experiments were conducted under irrigated condition.

\subsection{Experiment 1. Planting Arrangement and Population Density}

Seeds of two hybrids of white maize (PSC 121and KS 510) were planted in well prepared seedbeds during October 22 through October 28, 2015. The experiment considered planting arrangement and population density effect on yield of maize hybrids. Seeds of two hybrids (KS 510 and PSC121) were planted each at three different row arrangements - single rows at $60 \mathrm{~cm} \times 25 \mathrm{~cm}, 50 \mathrm{~cm} \times 25 \mathrm{~cm}$, and twin rows. Distance between twin rows was $30 \mathrm{~cm}$ interspersed with $70 \mathrm{~cm}$ between two twin- rows with $25 \mathrm{~cm}$ between plants in the row. A blanket rate of fertilizers (200 $\mathrm{kg} \mathrm{N}, 50 \mathrm{~kg} \mathrm{P}, 100 \mathrm{~kg} \mathrm{~K}, 31.25 \mathrm{~kg} \mathrm{~S}, 3.5 \mathrm{~kg} \mathrm{Zn}$, and $2.5 \mathrm{~kg} \mathrm{~B}$ per ha) was applied in all the plots. Nitrogen was applied in three equal splits- at the end of land preparation immediately prior to planting seeds, first topdressing at 6-leaf stage, and final topdressing at 12-leaf stage. The experiment was laid out in a split-plot design with five replications, each farmer's plot being considered a replication. Planting arrangement (main plot) and hybrid (sub-plot) were the treatment variables. Since plot size differed across farmers' plots, number of maize rows and length of rows varied. However, the smallest sub-plot (Thwingyapara) consisted of 16 rows, each $26 \mathrm{~m}$ long. The largest sub-plot (Charuipara) was $39 \mathrm{~m}$ long $14 \mathrm{~m}$ wide. A light irrigation was applied immediately after planting seeds. Seven days after planting, seedlings were thinned out keeping a single seedling per grid. Adequate care was taken to avoid biotic- and abiotic stresses. Weeding was done two-three times until full canopy development. There had been incidence of repeated pest attacks from seedling stage to silking stages and measures were taken to keep the damage to a minimum.

\subsection{Experiment 2: Effect of Fertilizer Application}

The effect of variable rates of fertilizers was investigated in order to determine appropriate rate of fertilizer application for white maize in the valley. The two-factor experiment was accommodated in a split-plot design with fertilizer rate in the main plot and hybrid in the sub-plot. The experiment was replicated in four farmers' plots. Two hybrids - KS-510, and PSC-121 and three variable rates of fertilizers - (i) full amount of recommended rate of fertilizers i.e., $230 \mathrm{~kg} \mathrm{~N}, 50$ $\mathrm{kg} \mathrm{P}, 100 \mathrm{~kg} \mathrm{~K}, 31.25 \mathrm{~kg} \mathrm{~S}, 3.5 \mathrm{~kg} \mathrm{Zn}$, and $2.5 \mathrm{~kg} \mathrm{~B}$ per ha in the form of urea, triple super phosphate, muriate of potash, gypsum, $\mathrm{ZnSO}_{4}$ and boric acid, (ii) $50 \%$ of recommended rate of fertilizers, and (iii) $25 \%$ of recommended rate of fertilizers formed the treatment variables. Three variable rates of fertilizers were assigned to each hybrid. One third of nitrogen and whole amount of other fertilizers were applied at final land preparation. Remaining nitrogen was top-dressed at two equal splits -once at 6-leaf stage and finally at 12-leaf stage. Seeds of maize hybrids were planted in rows at $60 \times 25$ $\mathrm{cm}$ configuration during the dry season, 2015-16. Adequate care was taken to raise the crop giving timely irrigation and protecting from pest attack.

\subsection{Measurements}

Irrespective of treatment differences, measurements of plant characters, yield components and grain yield was similar in both the experiments. At V3 stage [39] we demarcated an area of $10 \mathrm{~m}^{2}$ from the center of each sub-plot for determination of plant population density per unit area, plant height, grain yield and yield attributes. At cob maturity when most leaves of the plant turned straw color we harvested the cobs and counted the number of plants from the yield area and recorded the number of plants per $\mathrm{m}^{2}$ and number of ears per $\mathrm{m}^{2}$. The height of ten randomly selected plants from each sub-plot was measured from the base of the plant to the base of the tassel. Average height of ten plants was taken. The cobs of individual sub-plots of $10 \mathrm{~m}^{2}$ area were sun-dried, threshed with a corn-sheller, and grain dry weight and grain moisture content recorded. The grain dry weight of each unit plot was expressed into yield $(\mathrm{kg} / \mathrm{ha})$ adjusting at $13 \%$ moisture content [40]. Ten (10) ears were sampled at random from each sub-plot and the number of kernel-rows per ear was determined. The selected ears were threshed and the number of kernels per ear, and 1000 kernel weight recorded. The number of kernels per row in the ear was also computed.

\subsection{Statistical Analysis}

Data were subjected to Analysis of Variance (ANOVA) and means compared following LSD test at $p<0.05$ level of significance. 


\section{Results and Discussion}

Daily weather data for the growing season (October March) were collected from nearby SRDI Soil \& Water Conservation Research Station, Meghla. Temperature and rainfall data are displayed in Figure 1. Mean maximum temperatures varied between 20 and $36^{\circ} \mathrm{C}$, and mean minimum temperatures between 11 and $24^{\circ} \mathrm{C}$ during the growing season. The crop received a precipitation of $29 \mathrm{~mm}$ October 2015 through March 2016. From Figure 1 it is apparent that the air temperatures prevailing during the growing season remained within the optimal temperature range of 18 to $32^{\circ} \mathrm{C}$ [41] supporting growth and development of maize plant.

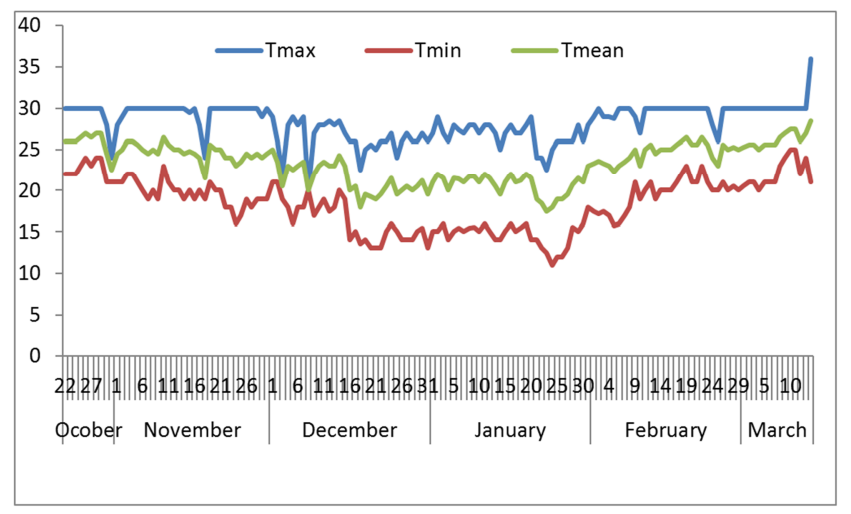

Figure 1. Variation in air temperatures $\left(\right.$ in ${ }^{\circ} \mathrm{C}$ ) at Bandarban during the growing season, October 2015-March 201.

\section{Experiment 1. Planting arrangement, population density} effects

Planting at wider spacing $(60 \mathrm{~cm} \times 25 \mathrm{~cm})$ gave a population density of 66,667 per ha while single row planting at $50 \mathrm{~cm}$ wide rows with $25 \mathrm{~cm}$ interplant distance, and planting in twin-rows $30 \mathrm{~cm}$ apart and interspersed with 70 $\mathrm{cm}$ between two pairs gave higher but similar density of 80,000 plants per ha. However, population at harvest differed slightly from the targeted populations or the actual populations established in the beginning (Table 1).

Plant morphological characters: Plants of both the hybrids were rather tall that ranged between 242 and $288 \mathrm{~cm}$. Of the two hybrids, PSC 121 was significantly taller than KS 510. Plant height increased with increasing planting density.

Yield attributes: Both the hybrids produced identical number of ears per plant giving an average of 0.98 ears. Planting arrangement also did not affect the number of ears per plant. Number of ears per plant seems to be a fairly stable genotypic character [42]. Our findings are in agreement with Sharifi et al. [43] who obtained no significant variation among the hybrids in number of ears per plant. Interaction effect of hybrid x planting arrangement on the number of ears per plant was, however, statistically significant with PSC 121 planted in twin rows showing the highest number of ears per plant which was closely followed by KS 510 planted at 60 $\mathrm{cm} \times 25 \mathrm{~cm}$ configuration (Table 1).

Barren ears or ears with unfilled grains, smaller in size, partially or fully barren ears were considered deformed. Barrenness is the failure of a plant to produce a normal ear [44]. Table 1 shows the extent of ear barrenness or deformed ears as affected by planting arrangements. Difference in ear barrenness between the two hybrids was not significant suggesting that both the hybrids had identical ear barrenness. The percentage of ear barrenness was generally higher in maize planted in wider rows. Our results contrast with those of Sangoi [13] who reported increasing barrenness of ears with increasing plant competition due to higher planting density. Lesser percentage of deformed ears or barrenness in our study might be associated with plant characters of modern hybrids which are more tolerant to plant competition [45]. Planting density in the present study differed from 66,667 to 80,000 and the crowding effect as evidenced from higher density might be absent. Greater percentage of ear barrenness in lesser population density at wider row might be associated with partitioning of photoassimilates during postanthesis phase.

Table 1. Effect of hybrids and planting arrangements on plant morphological characters of maize.

\begin{tabular}{|c|c|c|c|c|c|}
\hline Planting arrangement & Hybrids & Plant ht. (cm) & No. ears/plant & Barren (deformed) ears (\%) & Ear length $(\mathrm{cm})$ \\
\hline $60 \mathrm{~cm} \times 25 \mathrm{~cm}$ & PSC-121 & 259 & 0.91 & 39 & 16.87 \\
\hline $60 \mathrm{~cm} \times 25 \mathrm{~cm}$ & KS -510 & 242 & 1.03 & 12 & 18.87 \\
\hline $50 \mathrm{~cm} \times 25 \mathrm{~cm}$ & PSC-121 & 257 & 0.94 & 8 & 16.94 \\
\hline $50 \mathrm{~cm} \times 25 \mathrm{~cm}$ & KS-510 & 272 & 0.94 & 20 & 18.25 \\
\hline Twin-row & PSC-121 & 288 & 1.06 & 20 & 16.95 \\
\hline Twin row & KS -510 & 273 & 1.00 & 26 & 19.98 \\
\hline LSD 0.05 & & & & & \\
\hline for hybrid & & 14 & 0.07 & ns & 2.08 \\
\hline for planting arrangement & & 9 & ns & 12 & ns \\
\hline for hybrid $\mathrm{x}$ pl arrangement & & ns & 0.11 & ns & ns \\
\hline
\end{tabular}

The number of kernels per ear is a function of ear length and kernel rows per ear. Ear length differed from $16.87 \mathrm{~cm}$ to $19.98 \mathrm{~cm}$ across hybrids and planting arrangements. Hybrid KS 510 planted in twin -rows tended to produce longer $(19.98 \mathrm{~cm})$ ears while PSC 121 planted at $60 \mathrm{~cm}$ wide rows the smallest ears; but hybrid and planting arrangement interaction effect on ear length was not statistically significant. Absence of genotype $x$ planting density interaction on ear length or kernel rows per ear indicates stress tolerance of modern maize hybrids to crowding [46]. 
Shafi et al. [47] working with four maize varieties grown in three variable population densities observed decreasing ear length with increasing population density. Malaviarachchi et al. [48], however, observed no significant variation in ear length across a wide range of population densities.

Number of kernel rows per ear and the number of kernels per row make up the number of grains per plant. Grain yield per plant is the result of the number of grains per plant times the individual weight of a grain. Both the hybrids produced identical number of kernel rows per ear (Table 2) but planting arrangement affected the number of kernel rows per ear significantly. Planting in wide rows or in twin-rows resulted in identical but significantly lower number of kernel rows per ear compared with narrow rows at $50 \mathrm{~cm}$, which agrees with Abuzar et al. [14] who observed progressive decrease in kernel rows per ear with increasing plant density from 60,000 to 140,000 plants per ha suggesting that compared with other traits in modern hybrids the resistance of kernel rows per ear to plant competition might be less [12].

The number of grains per ear ranged between 468 and 516 across hybrids and planting arrangement treatments. Two hybrids differed significantly in the number of grains per ear. Hybrid KS 510 tended to produce more grains per ear than
PSC 121 but the difference between the hybrids was not statistically significant. Planting in single rows produced identical number of grains per ear while twin row planted maize gave significantly larger number of grains per ear (Table 2). Maize planted in twin rows produced significantly higher number of grains per ear compared to single rows. Planting in $50 \mathrm{~cm}$ or $60 \mathrm{~cm}$ row spacing had identical number of grains per ear. It appears that greater the ear length, larger was the number of grains produced per ear [27]. Variation in grain weight per ear differed significantly between the two hybrids with higher being in PSC 121. Planting arrangement was found to have no significant influence on grain weight per ear. Individual grain weight was determined using 100grain sub-samples. Five sub-samples each of 100 grains were taken from each sub-plot and average 100-grain weight was recorded. Table 2 indicates that hybrids exerted significant influence on individual grain weight. PSC 121 registered significantly higher 100-grain weight than KS 510. Reports abound on the adverse effect of increased planting density on the number of seeds per ear abound. Abuzar et al. [14] reported increasing population density adversely affected the number of grains per ear and individual grain weight.

Table 2. Hybrids and planting arrangement effect on yield contributing characters and grain yield of maize.

\begin{tabular}{|c|c|c|c|c|c|c|}
\hline Planting arrangement & Hybrids & No. kernel rows/ear & Grains/ear & 100-grain weight (g) & Grain wt/ear (g) & Grain yield (kg/ha) \\
\hline $60 \mathrm{~cm} \times 25 \mathrm{~cm}$ & PSC-121 & 13.5 & 468 & 34.039 & 206.1 & 9,074 \\
\hline $60 \mathrm{~cm} \times 25 \mathrm{~cm}$ & KS -510 & 13.75 & 480 & 33.188 & 195.3 & 7,103 \\
\hline $50 \mathrm{~cm} \times 25 \mathrm{~cm}$ & PSC-121 & 14 & 470 & 33.642 & 209.72 & 10,396 \\
\hline $50 \mathrm{~cm} \times 25 \mathrm{~cm}$ & KS -510 & 14.17 & 508 & 33.272 & 196.96 & 8,733 \\
\hline Twin-row & PSC-121 & 13.67 & 494 & 34.603 & 209.37 & 10,612 \\
\hline Twin row & $\mathrm{KS}-510$ & 13.75 & 516 & 33.33 & 197.78 & 9,610 \\
\hline \multicolumn{7}{|l|}{ LSD0.05 } \\
\hline for hybrids & & ns & ns & 0.63 & 7.22 & 327 \\
\hline for planting arrangements & & 0.14 & 17 & 1.45 & 9.88 & 625 \\
\hline for hybrid x pl. arrangements & & 0.18 & ns & ns & ns & ns \\
\hline
\end{tabular}

Grain yield: Hybrids and differential planting arrangements significantly influenced maize grain yield. Interaction effect of hybrids and planting arrangement on yield, however, was not significant (Table 2). Grain yield ranged between 7,103 $\mathrm{kg}$ and 10,612 $\mathrm{kg}$ per ha across hybrids and planting arrangements. Compared to KS 510, hybrid PSC 121 produced $18.22 \%$ higher yield than KS 510. Generally grain yield increased with increasing planting density. On an average, planting density of 80,000 per ha increased grain yield by nearly $18.22 \%$ compared with a density of 66,667 plants per ha. With identical planting densities, planting in twin rows gave significantly higher yield than planting in single rows at $50 \mathrm{~cm}$ x $25 \mathrm{~cm}$ configuration. Maize planted in twin-rows providing more equidistance gave 14\% higher yield compared with similar density planted at single rows. Variation in grain yield due to variable densities or row arrangements may be explained from the difference in the number of grains per ear or plant due to planting density [48, 49] or the space available per plant for growth [50]. Our results are in disagreement with earlier research on maize plant population densities with open pollinated varieties and synthetics during the 1980s and 1990s in Bangladesh [51] indicating lower optimal densities but in agreement with those of Biswas et al. [23] and Alam et al. [52]. The modern hybrid used in the present study seems to be more stress tolerant than the composites and older hybrids [13, 53] and capable of producing higher yield when planted in narrow rows.

Twin-row planting resulted in higher yield compared to single row planting. Averaged over hybrids, the overall yield increase in twin-row planting was nearly $12 \%$ compared with single row planting. Highest grain yield was recorded for PSC 121 planted in twin-rows followed by KS 510 planted at $50 \mathrm{~cm} \mathrm{x} 25 \mathrm{~cm}$ configuration. Generally, higher the population density greater was the yield. Planting in twin rows and decreasing inter-row spacing to $50 \mathrm{~cm}$ increased plant-to-plant spacing within the row, thereby promoting less inter-plant competition and greater yield [54-56]. Karlen et al. [33] also suggested that maize in twin-row system increased yield because the twin-row configuration, at 
comparable populations, decreases intra-row plant competition for plant growth resources.

Population density varied between 66,667 and 80,000 per ha. Both single row with $50 \mathrm{~cm} \times 25 \mathrm{~cm}$ configuration and a twin-row with $70 \mathrm{~cm} \times 25 \mathrm{~cm}$ configuration interspersed with $30 \mathrm{~cm}$ between the paired rows had 80000 plants per ha giving different canopy architecture. Although two distinctly different row arrangements gave similar plant density, variable planting arrangements resulted in variable canopy architecture giving variable light interception. Plant growth and grain yield formation is the function of canopy architecture and light interception. For maize plants, light interception for 30 days about silking is critical. Maize grain yield is mainly attributed to the number of kernels per $\mathrm{m}^{2}$ and the kernel weight. In the present study, PSC 121 planted in twin-rows, and KS 510 planted in rows $50 \mathrm{~cm} \times 25 \mathrm{~cm}$ had more number of kernels per ear than in other treatments. In PSC 121 planted in twin-row again, the kernel weight per ear was significantly higher giving the highest yield. Gozubenli et al. [57] also reported that with high but identical population, maize planted in twin rows out-yielded single row planting.

Grain yield determination in maize is a sequential process in which the potential number of ears per plant is determined first, followed by grain number per inflorescence and by grain size. Late initiated ear-shoots may receive smaller amount of photosynthates due to increased competition between the ear and other plant organs resulting in reduced number of kernels per ear. Increased competition due to dense population may also lead to abortion of ovary and eventually producing lesser number of kernels increasing barrenness [58]. Comparing the response of old and modern maize hybrids Sangoi and Salvador [59], however, reported that high plant population decreased number of grains per ear of dwarf lines and did not affect this variable for modern hybrids. Consequently, differences in yield between hybrids and dwarfs were greater at the higher plant populations.

Grain yield of maize is the product of the number of plants per unit area, number of ears per plant, grains per ear and individual grain weight [58]. Both genetic makeup and the photosynthetic efficiency greatly influence the grain yield and yield attributes in cereals. Physiological approach to improving grain yield of cereal crops stresses on improving biomass yield and more favorable partitioning of dry mass into grains [60-61]. Biomass production depends on radiation interception and conversion of $\mathrm{CO}_{2}$ into carbohydrates. Canopy architecture of a plant community largely regulates both radiation interception and acquisition of $\mathrm{CO}_{2}$ and thus plant productivity. Plant population density and planting arrangement influenced greatly on the canopy architecture leading to improved light interception and increased productivity.

\section{Experiment 2: Fertilizer effect}

In the present study the rate of fertilizers used as standard check (i.e., $100 \%$ of recommended rate) for growing white maize in the Bandarban valley was in fact recommended for the yellow maize grown in the northern districts of Bangladesh and hitherto no research report is available on the response of maize to fertilizer application in Bandarban or any hill district of Bangladesh. But the reports on soil properties and land suitability [34] indicate that soils in Bandarban valley are generally low to very low in plant nutrients except potassium, magnesium, iron and manganese.

Plant morphological characters: Table 3 shows the effect of fertilizer application on plant characters of maize. Plant height ranged between 243 and $279 \mathrm{~cm}$ across treatments with an average of $263 \mathrm{~cm}$. Generally plant height increased with increasing rate of fertilizer application. As was observed in Experiment 1, plants of hybrid PSC 121 were taller than KS 510.

Table 3. Influence of rate of fertilizer application on plant morphological characters of two hybrids of maize.

\begin{tabular}{|c|c|c|c|c|c|}
\hline Fertilizer rate & Hybrid & Plant height $(\mathrm{cm})$ & No. ears/plant & Deformed ears (\%) & Ear length $(\mathrm{cm})$ \\
\hline $100 \% \mathrm{RF}^{*}$ & PSC 121 & 273 & 0.91 & 29 & 18.09 \\
\hline $100 \% \mathrm{RF}$ & KS 510 & 279 & 1.03 & 27 & 17.54 \\
\hline $50 \% \mathrm{RF}$ & PSC 121 & 266 & 0.94 & 27 & 16.69 \\
\hline $50 \% \mathrm{RF}$ & KS 510 & 259 & 0.94 & 35 & 16.70 \\
\hline $25 \% \mathrm{RF}$ & PSC 121 & 266 & 1.06 & 29 & 17.07 \\
\hline $25 \% \mathrm{RF}$ & KS 510 & 243 & 1.00 & 38 & 16.56 \\
\hline CV $(\%)$ & & 19.31 & 11.73 & 22.80 & 17.52 \\
\hline
\end{tabular}

$* \mathrm{RF}$ - recommended rate of fertilizers

Yield attributes: Neither fertilizer application nor hybrids created any significant variation in the number of ears per plant. Regardless of treatment differences, $29.4 \%$ of ears were deformed or barren which was attributed to both hybrids and fertilizer application. Ear barrenness tended to be more in KS 510 than in PSC 121 but the difference was not statistically significant (Table 3 ). The results suggest that regardless of agronomic management both the hybrids are identical in ear barrenness. Application of fertilizers at $100 \% \mathrm{RC}$ reduced ear barrenness significantly. Reducing the fertilizer rate to $50 \%$ also reduced the percentage of ear barrenness identical to that of full amount of fertilizers but further reduction in fertilizer rate (i.e. $25 \%$ ) increased the ear barrenness significantly. Ear length varied between 16.56 and $18.09 \mathrm{~cm}$ across treatments. PSC 121 produced longer ears than KS 510. Decreasing the rate of fertilizers tended to decrease the ear length but the rate 
of change was not consistent (Table 3).

The number of kernel rows per ear varied between 13.8 and 15.4 among the treatments. Both hybrids and fertilizer treatments exerted significant influence on the number of kernel rows per ear. From Table 4 it is apparent that PSC 121 had more kernel rows per ear compared to KS 510. The effect of fertilizer application on the number of kernel rows per ear was not consistent. However, there was significant interaction of hybrid and fertilizer application on the number of kernel rows per ear (Figure 2). Application of 100\% recommended rate of fertilizers increased kernel rows per ear in PSC 121; but KS 510 showed the lowest number of kernel rows.

The number of grains per ear differed from 451 to 527 across the treatments with a mean of 473. Hybrid PSC 121 produced more number of grains per ear (496) compared to KS (450). Application of full amount of fertilizers increased the number of grains per ear significantly compared with the application $25 \%$ or $50 \%$ of recommended rate of fertilizers that produced identical but significantly lower number of grains per ear. Our results agree well with Selassie [63] who demonstrated that application of nitrogen fertilizer rates up to $200 \mathrm{~kg}$ per ha significantly increased kernel number per ear and number of ears per plant.

Grain weight per ear is an important criterion for expressing maize grain yield. Grain weight per ear depends on the number of grains per ear and individual grain weight. There was an enormous variation in 100-grain weight that ranged between 30.085 and $34.523 \mathrm{~g}$ across hybrids and fertilizer treatments. Table 4 shows that 100 grain weight was significantly higher in PSC 121 than in KS 510. Application of $100 \%$ or $50 \%$ of recommended rates of fertilizer had identical but significantly higher grain weight than that obtained with lower rate of fertilizer application. Our results compare favorably with those of Liu et al. [64] who obtained minimal increases in grain filling rate and grain size with doubling the rates of fertilizer application. However, Alam et al. [52] observed no significant variation in 100-grain weight due to variation in planting density or fertilizer rates.

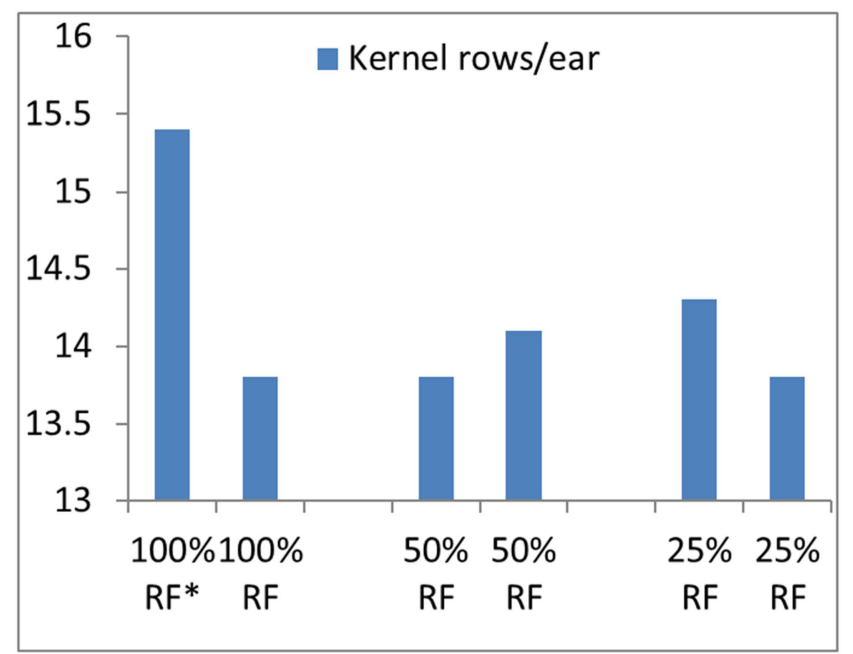

Figure 2. Effect of fertilizer rates on the number of kernel rows in two maize hybrids. $R F$ - recommended rate of fertilizers.

Grain weight per ear is an important criterion for expressing maize grain yield. The main contributing factor for the variation in grain yield is the number of kernels per ear. Hybrids differed significantly in grain weight per ear (Table 4). Highest grain weight per ear was recorded for PSC 121. Application of $50 \%$ and $25 \%$ of recommended rate of fertilizers tended to increase weight of grains per ear but the difference was not statistically significant. Difference in ear weight can be explained from the variation in individual grain weight and the number of grains per ear. As observed in experiment 1, hybrids differed greatly in grains per ear. Both hybrids and fertilizer exerted significant influence on 100-grain weight.

Table 4. Response of yield components and grain yield of two maize hybrids to variable rates of applied fertilizers.

\begin{tabular}{|c|c|c|c|c|c|c|}
\hline Fertilizer rate & Hybrid & No. kernel rows/ear & No. grains/ear & 100 grain wt (g) & Grain wt (g/ear) & Grain yield (kg/ha) \\
\hline $100 \% \mathrm{RF}^{*}$ & PSC 121 & 15.4 & 527 & 34.989 & 192.6 & 9,103 \\
\hline $100 \% \mathrm{RF}$ & KS 510 & 13.8 & 464 & 31.667 & 180.9 & 7,717 \\
\hline $50 \% \mathrm{RF}$ & PSC 121 & 13.8 & 487 & 34.523 & 203.4 & 8,434 \\
\hline $50 \% \mathrm{RF}$ & KS 510 & 14.1 & 435 & 30.871 & 181.6 & 7,403 \\
\hline $25 \% \mathrm{RF}$ & PSC 121 & 14.3 & 474 & 33.760 & 216.4 & 7,005 \\
\hline $25 \% \mathrm{RF}$ & KS 510 & 13.8 & 451 & 30.085 & 167.2 & 6,217 \\
\hline $\mathrm{CV} \%$ & & 4.77 & 12.58 & 8.43 & 18.63 & 15.63 \\
\hline \multicolumn{7}{|l|}{$\operatorname{LSD}(p<0.05)$} \\
\hline for hybrids & & 0.3 & 23 & 0.903 & 18.57 & 104 \\
\hline for fertilizers & & 0.42 & 28 & 0.746 & ns & 367 \\
\hline for hybrid $\mathrm{x}$ fert interaction & & 0.08 & ns & ns & ns & 429 \\
\hline
\end{tabular}

* RF - recommended rate of fertilizers

Grain yield: Grain yield ranged between 6,217 and $1,030 \mathrm{~kg}$ per ha across hybrids and fertilizer application treatments. Both hybrids and fertilizer application rate significantly influenced maize grain yield. Hybrid $\mathrm{x}$ fertilizer interaction on grain yield was not, however, statistically significant. Averaged over fertilizer treatments, PSC 121 produced higher yield than KS 510. From Table 4 it is apparent that maize grain yield increased linearly with increasing fertilizer 
application rates, the highest being recorded for the crop receiving $100 \%$ recommended rate of fertilizers. However, the yield difference between the highest rate and $50 \%$ of recommended rate of fertilizers was minimal (6\%). Fertilizer application of $25 \%$ of recommended rate significantly decreased yield giving the lowest yield. Our results compare favorably with those of Yong et al. [65] who observed significant increase in grain yield, economic coefficient, $\mathrm{N}, \mathrm{P}$ and $\mathrm{K}$ uptake, harvest index, $\mathrm{N}$ agronomic efficiency and $\mathrm{N}$ uptake efficiency of maize grown with $180 \mathrm{~N} \mathrm{~kg} \mathrm{ha}^{-1}$. Variation in grain due to application of variable rates of fertilizers could be explained mainly by variation in grain number and grain weight per plant. Grain weight was positively related with fertilizer application rate. It is probable higher rates of fertilizer application enhanced plant biomass production and grain growth rate during the critical growth stages.

\section{Conclusions}

Introduction of white maize is an attempt to increase food and nutritional security of the poor hill dwellers. Of the two hybrids, PSC 121 produced significantly higher yield compared to KS 510. The mean yield of hybrids across planting density treatments was $9,422 \mathrm{~kg}$ per ha which was $36 \%$ higher than national average and $306 \%$ higher than the average yield of maize in CHT. The clear yield advantage of hybrids over the traditional varieties or yellow maize hybrids can be considered a boon for the tribal farmers in CHT. Food security depends almost wholly on rice which is in short supply. Regional production of rice cannot meet the demand in CHT. Maize being the secondary staple crop for the tribal population, selection of hybrids and development of agronomic management practices may trigger its expanded cultivation.

Generally soils of Bangladesh are inherently poor in available plant nutrients and organic matter and most soils including those of CHT are deficient in nitrogen and phosphorus. Organic matter content is generally much lower than critical level indicating serious deficiency in N. This was reflected in the response of maize grain yield to applied fertilizers. An application of $150 \mathrm{~kg} \mathrm{~N}, 25 \mathrm{~kg} \mathrm{P}, 50 \mathrm{~kg} \mathrm{~K}, 15$ $\mathrm{kg} \mathrm{S}, 1.75 \mathrm{~kg} \mathrm{Zn}$, and $1.25 \mathrm{~kg}$ B per ha i.e. $50 \%$ of the rate of fertilizers recommended for the northern districts gave grain yield of $7,919 \mathrm{~kg}$ per ha which was identical with that obtained from $100 \%$ of recommended rate of fertilizer.

A population density of 80,000 plants per ha planted in twin-rows with a moderate dose of fertilizers may be recommended for growing white maize in Bandarban valley. However, as the effect of individual elements on the growth and yield formation in maize could not be determined, further studies could be undertaken for the determination of the amount of individual nutrients required for the realization of high yield potential in the Bandarban valley.

\section{Competing Interests}

The authors declare no competing interests.

\section{Acknowledgments}

This research was funded by Krishi Gobeshona Foundation. We thank Thwi Mong Marma (ARF), M. Faruk H. Mollah (BSMRAU), Professor M. Abdul Latif (SAU), M. Mabubul Islam (SRDI), Mohammad Abdul Wahab (CDB), and M. Mustaq Ahmed (OFRD, BARI) for their assistance. Cooperating farmers Anu Marma, Sui Hla Chin Marma, Aung Hsla Marma, Choing Marma, Mong Kya Chin, and Young Sung assisted us in running the experiments providing land and labor for which we thank them all.

\section{References}

[1] CASSMAN, K. G., GRASSINI, P., VAN WART, J. Crop yield potential, yield trends and global food security in a changing climate. In: Rosenzweig, C., Hillel, D. (Eds.), Handbook of Climate Change and Agroecosystems. Imperial College Press, London, p. 37, 2010.

[2] CHEN, X., CUI, Z., FAN, M., VITOUSEK, P., ZHAO, M., MA, W., WANG, Z., ZHANG, W., YAN, X., YANG, J., DENG, X., GAO, Q., ZHANG, Q., GUO, S., REN, J., LI, S., YE, Y., WANG, Z., HUANG, J., TANG, Q., SUN, Y., PENG, X., ZHANG, J., HE, M., ZHU, Y., XUE, J., WANG, G., WU, L., AN, N., WU, L., MA, L., ZHANG, W., ZHANG, F. Producing more grain without environmental costs. Nature 514, 486, October 13, 2014.

[3] DASS, S., KUMAR, A., JAT, S. L., PARIHAR, C. M., SINGH, A. K., CHIKKAPPA, G. K. JAT, M. L. Maize holds potential for diversification and livelihood security. Indian J. Agron. (Special Issue) 57: 86-91, 2012.

[4] RAY, D. K., MUELLER, N. D., WEST, P. C., FOLEY, J. A. Yield trends are insufficient to double global crop production by 2050. PLoS ONE 8, e66428, 2013.

[5] NUSS, E. T., TANUMIHARDJO, S. A. Maize: a paramount staple crop in the context of global nutrition. Compr. Rev. Food Sci. Food Saf. 9: 417-436, 2010.

[6] RANUM, P., PE`NA-ROSAS, J. P., GARCIA-CASAL, M. N. Global maize production, utilization, and consumption. Ann. N. Y. Acad. Sci. 1312 (2014) 105-112 C doi: 10.1111/nyas.12396, 2014.

[7] TIMSINA, J., JAT, M. L., MAJUMDAR, K. Rice-maize systems of South Asia: current status, future prospects and re- search priorities for nutrient management. Plant Soil, 335: 65-82, 2010.

[8] ALI, M. Y, WADDINGTON, S. R, TIMSINA, J., D. HODSON, D., DIXON, J. Maize-rice cropping systems in Bangladesh: Status and research needs. J. of Agric. Sci. Technol. 3 (6): 35-53, 2009.

[9] BANGLADESH BUREAU OF STATISTICS (BBS). Yearbook of Agricultural Statistics 2014. Ministry of Planning, Government of Bangladesh, Dhaka, 2016.

[10] TIMSINA, J., MAJUMDAR, K. Improved Nutrient Management in Rice-Maize Cropping Systems: A Case Study. Better Crops South Asia. 6 (1): 25-26, 2012.

[11] LEE, E. A., TOLLENAAR, D. M. Physiological basis of successful breeding strategies. Crop Sci. 47 (S3) S202-S215, 2007. 
[12] LEIBMAN, M., SHRYOCK, J. J., CLEMENTS, M. J.,. ALL, M. A., LOIDA, P. J., MCCLERREN, A. L., MCKINESS, Z. P., PHILLIPS, J. R., RICE, E. A., STARK, S. B. Comparative analysis of maize (Zea mays) crop performance: natural variation, incremental improvements and economic impacts. Plant Biotechnology Journal 12: 941-950. doi: 10.1111/pbi.12202, 2014.

[13] SANGOI, L. Understanding plant density effects on maize growth and development: an important issue to maximize grain yield. Ciência Rural, Santa Maria, 31: 159-168, 2000.

[14] ABUZAR, M. R., SADOZAI, G. U., BALOCH, M. S., BALOCH, A. A., H. SHAH, I., JAVAID, T., HUSSAIN, N. Effect of plant population densities on yield of maize. J. Animal Plant Sci. 21 (4): 692-695, 2011.

[15] ZAMIR, M. S. I., A. H. AHMAD, H. M. R. JAVEED AND T. LATIF. Growth and yield behaviour of two maize hybrids (Zea mays L.) towards different plant spacing. Cercetări Agronomiceîn Moldova. 14 (2): 33-40, 2011.

[16] EDWARDS, J. T., PURCELL, L. C., VORIES, E. D. Light interception and yield potential of short season maize hybrids in the Midsouth. Agron J. 97: 225-234, 2005 .

[17] OLSON, R. A., SANDERS, D. H. MAIZE PRODUCTION. IN: SPRAGUE, G. F. DUDLEY, J. W. Corn and corn improvement. American Society of Agronomy, Madison. pp. 639-686, 1988

[18] SARLANGUE, T., F. H. ANDRADE, P. A. CALVIÑO, AND L. C. PURCELL. Why do maize hybrids respond differently to variations in plant density? Agron. J. 99: 984-991. doi: 10.2134/agronj2006.0205, 2007.

[19] TOLLENAAR, M. Physiological basis of genetic improvement of maize hybrid in Ontario from 1959 to 1988. Crop Sci., 31: 119-124, 1991.

[20] LIU W., TOLLENAAR, M., SMITH, G. Within row plant spacing variability does not affect corn yield. Agron. J. 96: 275-280, 2004.

[21] ALFORD, C. M., D. STEPHEN, MILLER AND J. T. CECIL. Using row spacing to increase crop competition with weeds. In: Proc. 4th Int. Crop Science Congress, Birsbane Australia, 26 September-1 October, 2004.

[22] ANDRADE, F. H., SADRAS, V. O., VEGA, C. R. C., UHART, S., CIRILO, A., CANTARERO ECHARTE, L. Physiological determinants of crop growth and yield in maize, sunflower and soybean. J. Crop Improvement 14: 51-1001, 2005.

[23] BISWAS, M., RAHMAN, A. H. M. M., AHMED, F. Effect of variety and planting geometry on the growth and yield of hybrid maize. J. Agric. Env. Sci. 3 (2): 27-32, 2014.

[24] LIU, K., MA, B. L., LUAN, L. L, C. Nitrogen, phosphorus, and potassium nutrient effects on grain filling and yield of high-yielding summer corn. J. Plant Nutr. 34 (10): 1516-153, 2011.

[25] BENDER, R. R., HAEGELE, J. W., RUFFO, M. L., BELOW, F. E. Modern corn hybrids' nutrient uptake patterns. Better Crops 97 (1): 7-10, 2013.

[26] FAGERIA, N. K., BALIGAR, V. C. Enhancing nitrogen use efficiency in crop plants. Adv. Agron. 88: 97-185, 2005.
[27] SUBEDI, K. D., MA, B. L. Nitrogen uptake and partitioning in stay-green and leafy maize hybrids. Crop Sci. 45: 740-747, 2005.

[28] TAJUL, M. I., ALAM, M. M., HUSSAIN, S. M. M., NAHER, K., RAFII, M. Y., LATIF, M. A. Influence of plant population and nitrogen fertilizer at various levels on growth and growth efficiency of maize. The Scientific World J. Article ID 193018, 9 pp. DOI.org/10.1155/2013/193018, 2013.

[29] IBRAHIM, S. A. AND KANDIL, H. Growth, Yield and Chemical Constituents of Corn (Zea Affected by Nitrogen and Phosphorus Fertilization under Different Irrigation Intervals. Journal of Applied Sciences Research, 3, 11121120, 2007.

[30] BANERJEE, H., GOSWAMI, R., DUTTA, S. K., CHAKRABORTY, S., MAJUMDAR, K. Farm typologybased phosphorus management for maize in West Bengal. Better Crops- South Asia 9 (1): 8-11,

[31] KHAN, F., KHAN, S., FAHAD, S., FAISAL, S., HUSSAIN, S., ALI, S., ALI, A. Effect of Different Levels of Nitrogen and Phosphorus on the Phenology and Yield of Maize Varieties. American Journal of Plant Sciences, 5, 2582- 2590. http://dx.doi.org/10.4236/ajps.2014.517272, 2014.

[32] KARLEN, D. L., FLANNERY, R. L., AND SADLER, E. J. Aerial accumulation and partitioning of nutrients by corn. Agron. J. 80, 232-242, 1988.

[33] SMID, A. E., AND PEASLEE, D. E. Growth and carbon dioxide assimilation by corn as related to potassium nutrition and simulated canopy shading. Agron. J. 68: 904-908, 1976.

[34] SOIL RESOURCE DEVELOPMENT INSTITUTE (SRDI). User's Manual on Land and Soil Resources of Bandarban Sadar Upazila (in Bengali), Government of Bangladesh, Dhaka. 212 pp., 2010.

[35] VAUGHAN, A. K. F. The relation between the concentration of boron in the reproductive and vegetative organ of maize plants and their development. Rhod. J. Agric. Res. 15: 163$170,1977$.

[36] HOSSAIN, M. A., JAHIRUDDIN, M. F. KHATUN, M. F. Response of maize varieties to zinc fertilization. Bangladesh J. Agril. Res. 36 (3): 437-447, 2011.

[37] SHORROCKS, V. M., BLAZA, A. J. The boron nutrition of maize. Field Crop 25: 25-27, 1973.

[38] KHUONG, TQ, TAN, PS AND WITT, C. Improving of maize yield and profitability through site-specific nutrient management (SSNM) and planting density. Omonrice 16: 8892, 2008.

[39] HANWAY, J. J., RITCHIE, S. W. How a Corn Plant Develops: Special Report No. 48, Iowa State University, 1984.

[40] HELLEVANG, K. J. Grain moisture content effects and management. AE-905 (Revised), North Dakota State University Extension Service, Fargo, ND, USA. 8 pp., 1995.

[41] BELFIELD, S., BROWN, C. NSW Department of Primary Industry, Australia. 50 pp., 2008.

[42] MAPHUMULO, S. G., DERERA, J., QWABE, F., FATO, P., GASURA, E., MAFUNGOYA, P. Heritability and genetic gain for grain yield and path coefficient analysis of some agronomic traits in early-maturing maize hybrids. Euphytica 206: 225-244, 2015. 
[43] SHARIFI, R. S., SEDGHI, M., GHOLIPOURI, A. Effect of population density on yield and yield attributes of maize hybrids. Res. J. Biol. Sci. 4 (4): 375-379, 2009.

[44] BUREN, L. L. Plant characteristics associated with barrenness in maize. A Ph.D. dissertation submitted to Iowa State University, Ames, IA. 257 pp., 1970.

[45] SHAFI, M., BAKHT, J., ALI, S., KHAN, H., KHAN, M. A., SHARIF, M. Effect of planting density on phenology, growth and yield of maize (Zea mays L.). Pak. J. Bot., 44 (2): 691696, 2012.

[46] AL-NAGGAR, A. M., SHABANA, R. A., ATTA, M. M. M, AL-KHALIL, M. M. M. Maize response to elevated plant density combined with lowered $\mathrm{N}$-fertilizer rate is genotypedependent. Crop J. 3: 9 6-1 0 9, 2015.

[47] CARENA, M. J., CROSS, H. Z. Plant density and maize germplasm improvement in the northern corn belt. Maydica 48: 105-111, 2005.

[48] MALAVIARACHCHI, M. A. P. W. K., KARUNARATHNE, K. M., JAYAWARDANE, S. N. Influence of plant density on yield of hybrid maize (Zea mays L.) under supplementary irrigation. J. Agric. Sci. 3 (2): 58-66, 2007.

[49] MONNEVAUX, P., ZAIDI, P. H., SANCHEZ, C. Population density and low nitrogen affects yield associated traits in tropical maize. Crop Sci. 45: 533-545, 2005.

[50] ROBLES, M. R., CIAMPITTI, I. A., VYN, T. J. Responses of maize hybrids to twin-row spatial arrangement at multiple plant densities. Agron. J. 104: 1747-1756, 2012.

[51] ALI, M. Y., WADDINGTON, S. R., TIMSINA, J., HODSON, D., DIXON, J. Maize-rice cropping systems in Bangladesh: Status and research needs. Journal of Agricultural Science and Technology 3 (6): 35-52, 2009.

[52] ALAM, M. M., M. M. BASHER, KARIM, A., RAHMAN, M. A., ISLAM, M. R. 2009.2009. Effect of rate of nitrogen fertilizer and population density on the yield and yield attributes of maize (Zea mays) (in Bangladesh). Pak. J. Biol. Sci., 2003, 6: 1770-1773, 2009.

[53] BOOMSMA, C. R., SANTINI, J. B., TOLLENAAR, M., VYN, T. J. Maize morphological response to intense crowding and low nitrogen availability. An analysis and review. Agron. J. 101: 1426-1452, 2009.

[54] FARNHAM, D. E. Row spacing, plant density and hybrid effects on corn grain yield and moisture. Agron. J. 93: 10491053. doi: 10.2134/agronj2001.9351049x, 2001.
[55] THELEN, K. D. Interaction between row spacing and yield: Why it works. www.plantmanagementnetwork.org/cm/. Crop Manage. doi: 10.1094/CM-2006-0227-03-RV, 2006.

[56] HAEGELE, J. W., BECKER, R. J., HENNINGER, A. S., BELOW, F. E. Row arrangement, phosphorus fertility, and hybrid contributions to managing increased plant density of maize. Agron. J. 106: 1-9, 2014.

[57] FISCHER, R. A., EDMEADES, G. O. Breeding and cereal yield progresses. Crop Sci. 50: S85 - S98, 2010.

[58] GOZUBENLI, H., KILINK, M., SENER, O., KONUSKAN, O. Effects of single and twin row planting on yield and yield components in maize. Asian J. Plant Sci. 3 (2) 203-206, DOI: 10.3923/ajps.2004.203.206, 2004.

[59] JACOBS, B. J., PEARSON, C. J. Potential yield of maize determined by rates of growth and development of ears. Field Crops Res. 27: 281-298, 1991.

[60] SANGOI, L. AND R. J. SALVADOR, Influence of plant height and of leaf number on maize production at high plant densities. Pesqui. Agro. Brasilaria, 33: 297-306, 1998.

[61] REYNOLDS, M. P., SAINT PIERRE, C., SAAD, A. S. I., VARGAS, M., CONDON, A. G., Evaluating potential genetic gains in wheat associated with stress-adaptive trait expression in elite genetic resources under drought and heat stress. Crop Sci. 47, S172-S189, 2007.

[62] RICHARDS, R. A., REBETZKE, G. J., WATT, M., CONDON, A. G., SPIELMEYER, W., DOLFERUS, R. Breeding for improved water productivity in temperate cereals: Phenotyping, quantitative trait loci, markers and the selection environment. Funct. Plant Biol. 37, 85-97, 2010.

[63] SELASSIE, Y. G. The effect of $\mathrm{N}$ fertilizer rates on agronomic parameters, yield components and yields of maize grown on Alfisols of North-western Ethiopia. Environ Syst Res 4: 21, 2015.

[64] LIU, K., MA, B. L., LUAN, L. L, C. Nitrogen, phosphorus, and potassium nutrient effects on grain filling and yield of high-yielding summer corn. J. Plant Nutr. 34 (10): 1516-1531, 2011.

[65] YONG, T., LIEU, X., LIU, W, SU, B., SONG, C., YANG, F., WANG, X., YANG, W. Effects of reduced N application rate on yield and nutrient uptake and utilization in maize-soybean relay strip intercropping system (in Chinese). Ying Yong Sheng Tai Xue Bao 25 (2): 474-82, 2014. 